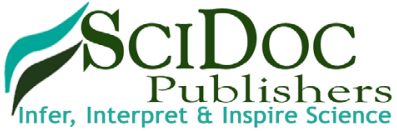

\section{Molecular Identification of Viruses Responsible for Severe Symptoms on Potato (Solanum sp.) grow- ing in Assiut Governorate (Upper Egypt)}

Research Article

Osama A. Abdalla*, Amal I. Eraky, Safynaz A. Mohamed, F. G. Fahmy

Department of Plant Pathology, Faculty of Agriculture, Assiut University, Assiut, Egypt.

Abstract

Severe viral-like symptoms were observed on potato plants growing in Assiut governorate (Upper Egypt) during 2010, 2011 and 2012 growing seasons. Typical viral-like particles were observed under Electron microscopy exanimation. These particles were either rod shape about $750 \mathrm{~nm}$ in length or bacilliform about $130 \mathrm{~nm}$ in length, and resemble Potato virusY (PVY) and Alfalfa mosaic virus (AMV) particles, respectively. Several biological, serological and molecular methods were applied to identify these particles. Serological tests proved that the causal viruses responsible for these symptoms were AMV and PVY. RNA extracted from infected potato as well as healthy potato plants was tested in Reverse Transcription Polymerase Chain Reaction (RT-PCR) using specific primers to amplifycoat protein gene of AMV or PYV. RT-PCR results proved that the symptomatic potato plants are being infected with AMV or PVY, either separately or simultaneously (mixed infection). To the best of our knowledge, this is the first molecular identification of AMV and PVY infecting potato in Assiut governorate, Upper Egypt.

Keywords: Potato; Alfalfa Mosaic Virus (AMV); Potato Virus Y (PVY).

\section{Introduction}

Cultivated potato (Solanum tuberosum spp. tuberosum) is the world's third most important food crop [19]. In Egypt, potato is considered as one of the most economic crops [15]. The cultivated area in Egypt is 178000 ha producing 4800000 tons [16]. Potato crops are being infected with many viruses which lead to great losses in potato production worldwide. More than 25 viruses have been reported to infect potato worldwide [8] and incur considerable yield losses in potato production, especially in African countries [29]. The average yield in African countries is $11800 \mathrm{Kg} / \mathrm{ha}$ compared to the world average yield of $16419 \mathrm{Kg} / \mathrm{ha}$, this reduction is mainly due to viral pathogens and other plant pathogens [29]. Among these viruses, Potato virus $Y$ (PVY) and Alfalfa mosaic virus (AMV) are being considered responsible for great losses in potato production annually. PVY has the potential to reduce potato yields up to $80 \%$ [23]. In Egypt, infection with PVY and/or AMV is being considered as one of the most limiting factor of potato production $[14,15,17]$. PVY has been isolated from several locations in Egypt since 1970 and causing devastating disease in potatoes [4].
While, AMV appears in potato fields in several potato production area in Egypt $[15,17]$.

During 2010-2012 growing seasons, severe viral-like symptoms including mosaic, leaves deformation, yellowing mottling and plant stunting were observed on potato plants growing in Assiut Governorate (Upper Egypt). These viral like symptoms led to great losses in potato production. This study was designed to biologically, serologically and molecularly identify the causal agent of this disease.

\section{Materials and Methods}

\section{Source of viruses}

Potato plants showing mosaic, mottling, yellowing, leaf deformation and stunting were collected from Experimental Farm, Faculty of Agriculture - Assiut University, Assiut, Upper Egypt, Egypt during 2010-2013 growing seasons. The viruses were mechanically inoculated into potato plants (Burna variety) and maintained

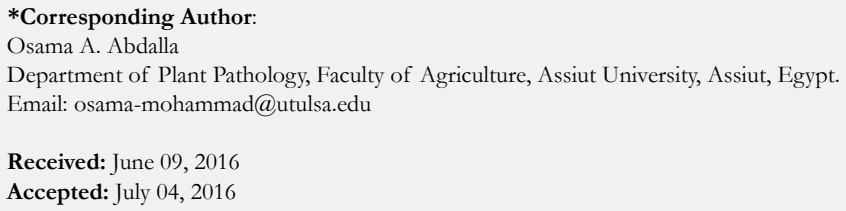

Copyright: Abdalla $\mathbf{O A}^{\circ}$ 2016. This is an open-access article distributed under the terms of the Creative Commons Attribution License, which permits unrestricted use, distribution and reproduction in any medium, provided the original author and source are credited. 
under greenhouse conditions.

\section{Electron Microscopy Examination (TEM)}

Sap of symptomatic potato leaves were examined under electron microscopy (JEM 100CX11-EM at The Electron Microscope Unit, University of Assiut, Assiut, using negative staining method as described by Reynolds, (1963) [26]. The grids were placed on the top of infectious sap drops for one minand left to dry. The grids were immersed in $2 \%$ phosphotungic acid $\mathrm{pH} 7.0$ for negative staining. Later the stained grids were raised with a fine tip forceps to the electron microscope for examination and description of virus particles shape and to determine their dimensions.

\section{Serological tests}

Several serological tests were applied to identifythe casual viruses responsible for severe symptoms on potato growing in Assiut governorate, including;

A:Precipitation drop method (PDM): The sap of symptomatic potato leaves were tested in PDM as described by Dounin and Papova (1937) [13], using different specific antiserum against the most five common viruses infecting potatoes plants worldwide, including Alfalfa mosaic virus (AMV), Potato virus $M$ (PVM), Potato virus S (PVS), Potato virus Y (PVY), and Potato virus X (PVX). The antiserums were obtained from All.UnionRes.Inst.Pl.Prot. Saint Petersburg, Russia, except antiserum of AMV and PVX which were kindly obtained from Dr. Ali .M.Abd El-Salam, Faculty of Agriculture, Cairo University. Crude sap from diseased potato variety was clarified by centrifugation at $300 \mathrm{rpm}$ for $5 \mathrm{~min}$. A drop of clarified leaf sap from infected plant was added on the right or the left slide of a microscopic slide surface. Another drop from the specific antiserum was placed onto the first one. Slides were examined under a microscope in dark field at a magnification of 50X. Checks were made using free serum.

\section{B. Indirect Enzyme-linked immunosorbent assay (ELISA):} To confirm PDM results, the symptomatic potato plants were further serologically tested by using specific antibodies against either AMV or PVY in ELISA tests as described by Clark and Adams (1977) [10]; Converse and Martin (1990) [11] with some modifications as follow: Micro-titer plates were coated with $100 \mu \mathrm{l} /$ well of leaf extract diluted to $1 / 10$ in coating buffer, $\mathrm{pH}$ 9.6, and incubated overnight at $4^{\circ} \mathrm{C}$. Wells were washed 3 times with PBST by shaking for $3 \mathrm{~min}$ each time. The plates were dried without washing, and cross-absorbed antiserum was then added at a dilution of $1 / 1000(100 \mu \mathrm{l} /$ well $)$. Plates were then incubated for three hr. at $37^{\circ} \mathrm{C}$ and then washed and dried. The antigen was detected with anti-rabbit alkaline phosphatase conjugate buffer, $\mathrm{pH} 7.4$, added to the plates using $100 \mu \mathrm{l} /$ well and incubated for $3 \mathrm{hr}$. at $37^{\circ} \mathrm{C}$. The plates were washed and dried. Para-nitro phenyl phosphate, PNPP, $(1.0 \mathrm{mg} / \mathrm{ml})$ dissolved in substrate buffer, $\mathrm{pH} 9.8$, was added. An absorbance value at 405 value at $405 \mathrm{~nm}$ of $2.5 \mathrm{x}$ the healthy control reading was used as the positive threshold [30].

\section{Bioassay Test}

AMV \& PVY were mechanically inoculated separately in several hosts belong to Amaranthaceae, Fabaceae, and Solanaceae. Leaf sap from infected potato with either AMV or PVY (based on ELISA tests) was inoculated into these hosts to biologically assay the severity of both AMV and PVY viruses. Leaf sap was diluted 1:5 in phosphate buffer $01 \mathrm{M} \mathrm{pH} 7.2$ and inoculated into leaves of tested plants by rubbing carborundum dust leaves. Inoculated plants were grown in a greenhouse at 18 to $22^{\circ} \mathrm{C}$ and observed every 3 days for symptoms. The plants were watered and nutrients were provided as required.

\section{Reverse transcription-Polymerase chain reaction (RT-PCR)}

Infected potato plants with either AMV or PVY (based on ELSA tests) were collected from experimental farm of faculty of Agriculture-Assiut University, during 2013 growing season. Total RNA was extracted from these symptomatic potato leaves as well as from healthy plants using the Tri-reagent method (Molecular Research Center Inc., USA), as described before in Abdalla and Ali (2012a) [1]. The complementary DNA was synthesized using MMLV-RT reverse transcriptase enzyme (Biochain, USA), according to the manufacturer's instructions. PCR amplification was carried out using virus-specific forward and reverse primers to amplify the coat protein (CP) gene of either AMV or PVY as described before in Ali et al., (2012) [3]. Primers to amplify CP of AMV included forward AMV: 5' GTCCGCGATCTCTTAAAT 3' and reverse AMV: 5' GAAG-T'T'TGGGTCGAGAGA $3^{\prime}$ as described by Abdalla and Ali (2012b) [2]. While, Primers to amplify CP of PVYincluded forward PVY: 5'-GATGGTTGCCTTGGATGATG '3 and Reverse PVY: 5'-TAAAAGTAGTACAGGAAA AGCCA as described in Cardin and Moury (2008) [9]. The PCR products were analyzed on $1 \%$ agarose gel, visualized with ethidium bromide and examined under UV [27].

\section{Results}

\section{Electron Microscopy Examination (TEM)}

Examination of symptomatic potato sap under electron microscopy, showed rod shape particles about $730 \mathrm{~nm}$ in length $x 10 \mathrm{~nm}$ in width, Figure (1a), and bacilliform particles about $50 \mathrm{~nm}$ in length. These particles resembled typical Potato virus $Y$ and Alfalfa mosaic virus Particles, respectively.

\section{Serological tests}

Testing sap from symptomatic potato leaves, using antiserum against five different viruses in drop precipitation test, revealed that the sap of infected potato reacted positively with antiserum of AMV and PVY. These results were confirmed in ELISA tests using mono-antibodies against AMV and PVY Table (1).

\section{Bioassay}

Certain Fabaceae and solanaceous hosts, as well as diagnostic plant were mechanically inoculated in separate way with AMV or PVY. Results showed that these two viruses have the potential to cause symptoms in these hosts. These symptoms ranged from moderate to severe symptoms. The most severe symptoms appeared in case of PVY inoculation into tomato or petunia plants, as PVY caused very severe symptoms included mosaic, mottling, vein clearing and leaf deformation in these solanaceous crops $\mathrm{Ta}$ ble (2) \& Figure (2). Inoculation of Chenopodium amaranticolor L. with PVY produced local lesion as amain character of this virus Table (2). 
Figure 1. Electron micrograph 1a: Typical rod shape particles about $730 \mathrm{~nm}$ in length \& 1b: Typical bacilliform particles about $130 \mathrm{~nm}$ in length.

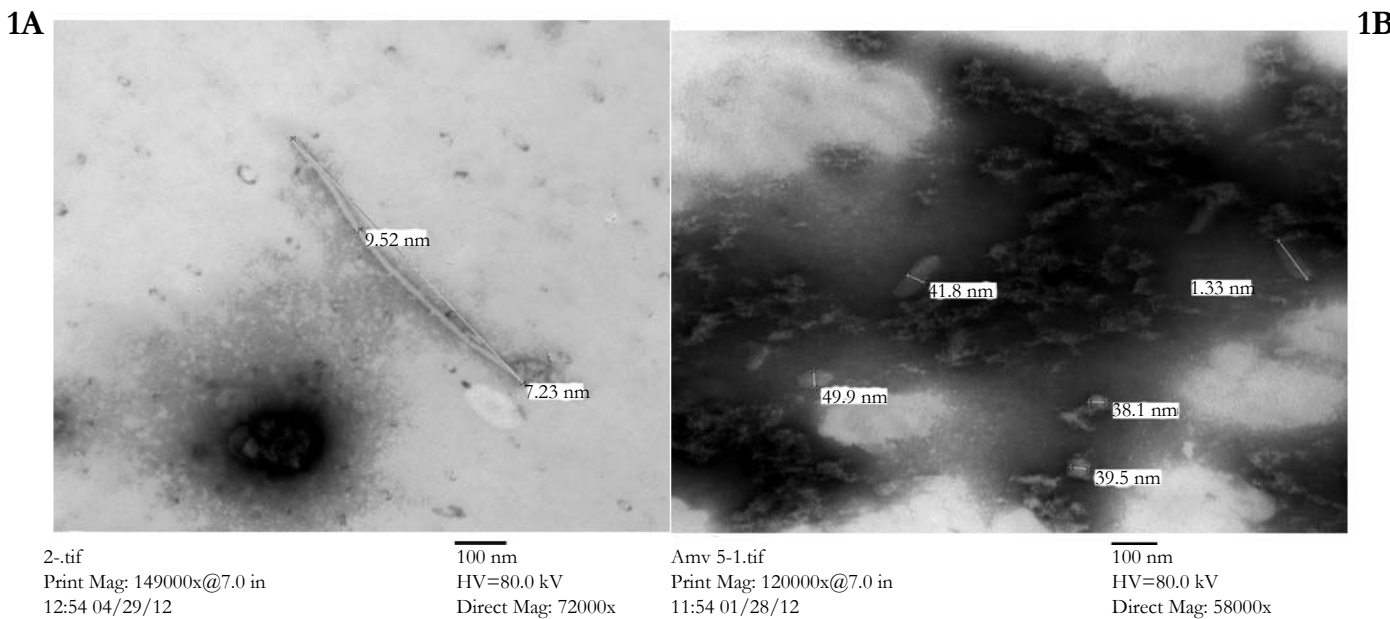

Table 1. Reaction of infected potato sap in serological tests.

\begin{tabular}{|c|c|c|}
\hline virus & DPM & ELISA \\
\hline AMV & ++ & ++ \\
\hline PVM & - & NT \\
\hline PVS & - & NT \\
\hline PVY & ++ & ++ \\
\hline PVX & - & NT \\
\hline
\end{tabular}

$\mathrm{AMV}=$ Alfalfa mosaic virus $\& \mathrm{PVM}=$ Potato virus $M \& \mathrm{PVS}=$ Potato virus $S \& \mathrm{PVY}=$ Potato virus $Y \& \mathrm{PVX}=$ Potato virus $X \& \mathrm{NT}=$ not tested.

Table 2. Reaction of certain hosts and diagnostic plant to mechanical inoculation with AMV and PVY (separately).

\begin{tabular}{|c|c|c|c|}
\hline Family & Host & $\begin{array}{l}\text { Reaction to AMV } \\
\text { Inoculation }\end{array}$ & $\begin{array}{c}\text { Reaction to PVY } \\
\text { inoculation }\end{array}$ \\
\hline Amaranthaceae & $\begin{array}{c}\text { Chenopodium amaranticolor } \\
\text { (Mexican tea) }\end{array}$ & - & LL \\
\hline Fabaceae & $\begin{array}{l}\text { Lupinus termis L. } \\
\text { (white lupine) }\end{array}$ & L.L. & - \\
\hline Fabaceae & $\begin{array}{c}\text { Phaseolus vulgaris L (Kidney } \\
\text { beans }\end{array}$ & L.L. & - \\
\hline Fabaceae & Psendo-acacia L (Locust tree) & M.L.L. & LL \\
\hline Fabaceae & Vicia faba L.Broad bean & L.L & - \\
\hline Solanaceae & $\begin{array}{l}\text { Solanum lycopersicum } \\
\text { Cherry tomatoes. }\end{array}$ & V.Cl., S, & VC- CL- M \\
\hline Solanaceae & $\begin{array}{l}\text { Petunia bybrida L. } \\
\text { (Petunia) }\end{array}$ & $\begin{array}{l}\text { T. V.S.S.Calico } \\
\text { mosaic. }\end{array}$ & VC- LD_M- \\
\hline
\end{tabular}

LL: Local lesion \& $\mathrm{M}=$ mosaic \& $\mathrm{V} \cdot \mathrm{Cl}=$ vein chlorosis \& $\mathrm{LD}=$ leaf deformation.

\section{Reverse transcription-Polymerase chain reaction (RT-PCR)}

Presence of AMV and PYV in symptomatic potato plants was tested in RT-PCR test. Specific primers to amplify CP genes of AMV and PVY separately were used in this test. Analysis of PCR products amplified by these primers through gel electrophoresis, showed that these specific primers amplified the expected size of 800 and 900 bp for AMV or PVY, respectively Figure (3), indicat- ing the presence of these viruses in infected potato plants. Using these specific primers with RNA extracted from healthy potato plants did not produce any PCR products (band), proving that these primers were very specific with either AMV or PVY. Results of RT-PCR also revealed that some of symptomatic potato plants were infected with either only one virus (AMV or PVY) or simultaneously infected with the two viruses Table (3). 
Figure 2. Symptoms produced on garden petunia Petunia hybrida L. after mechanical inoculation: $2 a=$ Inoculation withAMV \& 2b= Inoculation with PVY.

2A
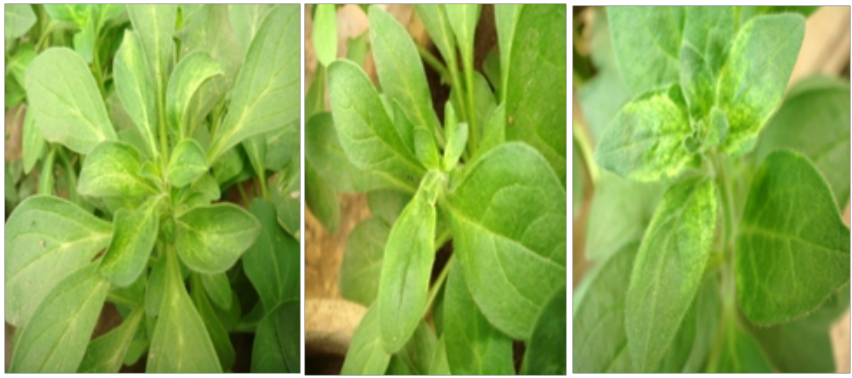

2B

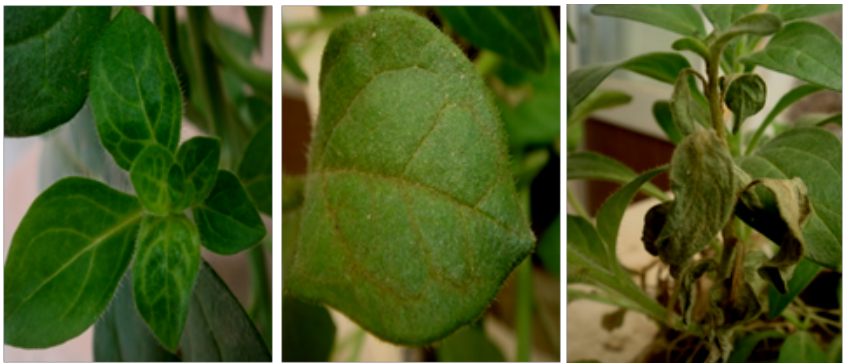

Figure 3. Gel electrophoresis of PCR products amplified using specific primers to A: To amplify CP gene of AMV. B: To amplify CP gene of PVY

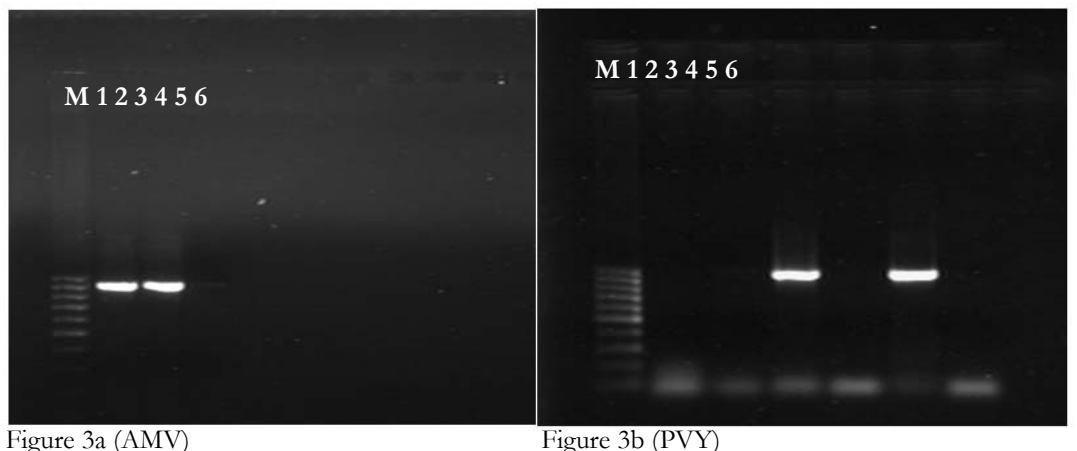

Table 3. RT-PCR results of tested potato plants against AMV and PVY.

\begin{tabular}{|c|c|c|}
\hline \multirow{2}{*}{ plant } & \multicolumn{2}{|c|}{ Tested Viruses } \\
\cline { 2 - 3 } & AMV & PVY \\
\hline 1 & + & + \\
\hline 2 & + & - \\
\hline 3 & + & + \\
\hline 4 & - & - \\
\hline 5 & - & + \\
\hline 6 (Healthy) & - & - \\
\hline
\end{tabular}

$\mathrm{AMV}=$ Alfalfa mosaic virus

\& PVY= Potato virus $Y$

\section{Discussion}

Severe viral-like symptoms were observed on potato plants growing in Assiut governorate during 2010-2013 growing seasons. These symptoms greatly reduced potato production. Identification of viruses responsible for symptoms is the first step to designa strategy to control plant viruses [3].

Examination of infected potato sap under Electron microscopy showed typical bacilliform particles about 130nm length x $40 \mathrm{~nm}$ width, and rod shape particles about $730 \mathrm{~nm}$ in length and $10 \mathrm{~nm}$ in width. These particles are typically resembling Alfalfa mosaic virus and Potato virus $Y$ particles, respectively, as described before by Gibbs et al., (1963) [18]; Varma et al., (1968) [28].

Mechanical Inoculation of these viruses into several diagnostic hosts produced local lesion in Chenopodium amaranticolor, and severe symptoms in several economic fabaceous and solanaceous crops. Both AMV and PVY have a wide host range [22, 24, 31]. AMV can infect more than 400 host [25], while PVY can infect many solanaceous crops, including potato, tomato and pepper [12]. Results showed that Inoculation of PVY into Chenopodium 
amaranticolor produced local lesion as a typical pattern of PVY infection in this host. Using Chenopodium amaranticolor in diagnosis of plant viruses is useful tool for testing plant viruses [21].

Sap of infected potato plants was serologically tested in drop precipitation test. Six different antiserums were used in DPT and revealed that the infected potato reacted positively with antiserum of AMV and PVY. These results were further confirmed through testing the infected sap using specific mono-antibodies against AMV and PVY in ELISA test. ELISA is one of the most used serological tests for the detection of potato viruses, mainly because of factors such as rapidity, low cost, and reliability [29]. But false positive is also common in ELSA tests due to that serologically related viruses may react with the same mono-antibody, and high concentration (titer of virus) are still needed for accurate results [6]. Thus, efforts to serologically detect AMV in infected hosts have historically been problematic mainly due to fluctuations in virus concentration, decrease in specific infectivity in tissues of infected plants and plant age [20].

It was found that using RT-PCR is very effective to detect potato viruses even after storage of tuber at $10^{\circ} \mathrm{C}$ [7]. So, detection depending on nucleic acid method like RT-PCR is the best method to detect potato viruses [29].

RNA extracted from leaves of infected potato with either AMV or PVY (based on ELISA results) was tested in RT-PCR, by using specific primers to amplify the CP genes of AMV or PVY separately. RT-PCR result confirmed the presence of AMV and PYV in symptomatic potato plants. The tested potato plants were either infected with one virus (single infection), while some plants were infected with the two viruses simultaneously. Mixed Infection with AMV \& PVY usually resulted in severer symptoms compared with symptoms occurred in case of single infection. May this severity is due to the suppression of post-transcriptional gene silencing by one virus, and this is will allow increase in replication rate of the another virus and severity of the symptoms [5].

These results proved that AMV and PVY are the main viruses infecting potato in Assiut governorate, and are in agreement with previous findings which reported that AMV and PVY are the main viruses infecting potato crop in Egypt and responsible for epidemic infection in potato fields $[4,14,15,17]$.

Although AMV and PVY have been molecularly identified before in Delta region, Egypt, but to the best of our knowledge, this is the first molecular identification of AMV and PVY to infect potato crops in Upper Egypt. Further studies are required to determine the genetic relationship between AMV and PVY isolates form Upper Egypt and other Egyptian and worldwide isolates.

\section{References}

[1]. Abdalla OA, Ali A (2012a) Genetic diversity in the 3-terminal region of Papaya ring spot virus (PRSV-W) isolates from watermelon in Oklahoma. Archive of virology 157(3): 405-412.

[2]. Abdalla OA, Ali A (2012b) First report of Alfalfa mosaic virus associated with severe mosaic and mottling of pepper (Capsicum annuum) and white clover (Trifolium repens) in Oklahoma. Plant Disease 96(11): 1705.

[3]. Ali A, Mohammad O, Khattab A (2012) Distribution of viruses infecting cucurbit crops and isolation of potential new virus-like sequences from weeds in Oklahoma. Plant Disease 96(2): 243-248.

[4]. Amer MA, Hammady MH, Mazyad HM, Shalaby AA, Abo-El-abbas FM (2004) Cloning, Expression and Nucleotide sequences of coat protein gene ofan Egyptian isolate of Potato virus $Y$ strain NTN infecting potato plants. Egyptian Journal of Virology 1: 39-51.

[5]. Anjos JR, Jarlfors U, Gabrial SA (1992) Soybean mosaic potyvirus enhances the titer of comovirus in dually infected soybean plants. Phytopathology 82: $17-23$.

[6]. Bar-Joseph SM, garnsey SM, Gonsalves D, Moscovitz M, Purcifull DE, et al., (1979) The Use of Enzyme-Linked Immunosorbent Assay for Detection of Citrus Tristeza Virus. Phytopathology 69(2): 190-194.

[7]. Barker H, Webster Kd, Revy B (1993) Detection of Potato virus $Y$ in potato tuber: a comparison of polymerase chain reaction and enzyme liked immunosorbent assay. Potato Research 36(1): 13-20.

[8]. Beemstar, A. B., and Rozendaal, A. 1972. Potato viruses: properties and symptoms. In: viruses of potatoes and seed potatoes production, De Boks, J.A. center Agriculture public and Documentation, wageningen, Netherlands. 115-143.

[9]. Cardin L, Moury B (2008) First report of Potato virus $Y$ in Nicotiana mutabilis in France. Plant Disease 92(2): 312.

[10]. Clark MF, Adams AM (1977) Characterization of the 2microplate method of enzyme-linked immunosorbent assay for the detection of plant viruses. Journal of General Virology 34(3): 475-483.

[11]. Conversre H, Martin RR (1990) ELISA methods for plant viruses: In Serological methods for detection and identification of viral and bacterial plant pathogens. ( $2^{\text {nd }}$ edn), APS press, St. Paul, Minnesota.

[12]. De Bokx JA, H Huttinga (1981) Potato virus Y: Description of plant viruses. Commonw Mycol Inst, Assoc Appl Biol, England. 241.

[13]. Dounin MS, popova NN (1937) The drop method of virus diagnosis in plant husdbandary. Co-op.farming Sekhozgiz, Moscow. 48.

[14]. El-Absway EA, Mahmoud A, Hemeida AA, Helmy M (2012) Molecular variation of Potato virus $Y$ isolated from Egypt. Inter. Journal of Virology 8(1): 81-89.

[15]. El-Helaly HS, Ahmed AA, Awad MA, Soliman AM (2012) Biological and Molecular characaterization of potato infecting Alfalfa mosaic virus in Egypt. International Journal of Virology 8(1): 106-113.

[16]. Food and Agriculture Organization of the United Nations, FAOSTAT database (FAOSTAT, 2013), available at http://faostat.fao.org/site/567/DesktopDefault $\mathrm{r}$.

[17]. Gamal Eldin AS, Abdel-Stattar, Maissa-Awad, Shalaby AA (1994) Isolation and identification of Alfalfa mosaic virus (AMV) from potato plants in Egypt. Proceedings of the 7th Congress of Phytopathology, Giza. 314-326.

[18]. Gibbs AJ, Nixon HL, woods RD (1963) Properties of purified preparations of lucerne mosaic virus. Virology 19(4): 441-449.

[19]. Halterman D, Charowski A, Verchot J (2012) Potato, Viruses, and seed certification in the USA to provide healthy propagated tubers. Pest Technology 6(spl 1): 1-14.

[20]. He B, Hill JH, Hajimorad MR (2011) Factors to improve detection of Alfalfa mosaic virus in soybean. Plant Health Progress 26: 1- 5. doi: 10.1094/ PHP-2010-0926-02-RS.

[21]. Hollings M (1956) Chenopodium amaranticolor as a test plant for plant viruses. Plant Pathology 5(2): 57-60.

[22]. Jaspars EM, Bos L (1980) Alfalafa mosaic virus: In description of Plant viruses. Commonw Mycol Inst, Assoc Appl Biol, England. 229.

[23]. Khurana SMP (2000) Potato viruses: detection and management. African potato association Conference proceedings 5: 257-269.

[24]. Moreira AG, Kitajima EW, Rezende JAM (2010) Identification and partial characterization of a Carica papaya-infecting isolate of Alfalfa mosaic virus in Brazil. Journal of general plant pathology 76(2): 172-1751.

[25]. Parrella G, lanave C, Marchoux G, Finetti MM, Franco AD, et al., (2000) Evidence for two distinct subgroups of Alfalfa mosaic virus AMV from France and Italy and their relationship with other AMV strains. Archive of Virology 145(12): 2659-2667.

[26]. Reynolds ES (1963) The use of lead citrate at high $\mathrm{pH}$ as an elctron-opaque stain in electron microscopy. Journal of Cell biology 17(1): 208-213.

[27]. Sambrook J, Russell DW (2001) Molecular cloning: Alaoratory manual. Cold spring Harbot, New York.

[28]. Varma A, Gibbs AJ, Woods RD, finch JT (1968) Some observatioins on the structure of the filamentous particles of several plant viruses. Journal of General virology 2(1): 107 .

[29]. Wangai A, lelgut D (2001) Status of potato viruses in Africa. Plant Virology in sub-Saharan Africa. Proceedings of a Conference, IITA, Ibadan, Nigeria. 458.

[30]. Xu H, Nie J (2006) Identification, characterization and molecular detection of Alfalfa mosaic virus in Potato. Phytopathology 96(11): 1237-1242.

[31]. Yarimici NY, kilici H, ozdemir T (2014) detection of PVY (Potato virus Y), on potato cultivars using biological and molecular methods growing in southwest Turkey. The journal of animal\& plant sciences 24(5): 1525-1530. 